\title{
THE EFFECT OF CONSUMPTION VALUE ON ORGANIC FOOD PURCHASE INTENTION WITH THE MEDIATING ROLE OF CONSUMER INVOLVEMENT
}

\author{
Lojain AL WASETI \\ Istanbul Aydın University, Turkey \\ lojainwaseti@stu.aydin.edu.tr \\ https://orcid.org/0000-0002-8717-7188 \\ Müge İRFANOĞLU \\ İstanbul Aydın University, Türkiye \\ mugeirfanoglu@aydin.edu.tr \\ https://orcid.org/0000-0001-6415-455X
}

\begin{abstract}
Throughout the past years, worldwide interest in organic food has increased, as well as in Turkey. This study is done in Turkey to understand what affects the organic food purchase intention in terms of consumption values theory with the mediation of involvement. The findings of this study showed that there is a positive direct significant relationship between functional value (quality + price), and emotional value with the organic food purchase intention, there is a negative direct relationship between social value and organic food purchase intention. Involvement fully mediates the relationship between functional value-price and purchase intention, whereas it partially mediates the relationship between emotional value and purchase intention. Involvement positively affects the organic food purchase intention.
\end{abstract}

Anahtar Kelimeler: Organic Food, Consumption Value Theory, Involvement, Purchase Intention

\section{TÜKETIM DEĞERINIIN TÜKETICII ILGINLIĞİ MODERATÖRLÜĞÜNDE ORGANIK GIDA SATINALMA TUTUMUNA ETKISIININ İNCELENEMESI}

ÖZ

Son yıllarda, tüm dünyada olduğu gibi Türkiye'de de organik gıdaya olan ilgi artmıştır. Bu çalışmada, ilginlik değeri teorisi çerçevesinde, Türkiye'de organik gıda satın alma niyetinin hangi faktörler tarafından etkilendiği, ilginlik faktörü aracılığı ile anlaşılmaya çalışılmıştır. Bu çalışmanın bulguları, organik gıda satın alma niyetinde, fonksiyonel değer (kalite + fiyat) ve duygusal değer arasında pozitif yönde doğrudan anlamlı bir ilişki olduğunu, sosyal değer ile organik gıda satın alma niyeti arasında negatif doğrudan bir ilişki olduğunu göstermiştir. İlginlik, işlevsel değer-fiyat ile satın alma niyeti arasındaki ilişkiye tam aracılık ederken, duygusal değer ile satın alma niyeti arasındaki ilişkiye kısmen aracılık etmektedir. Son olarak, ilginlik organik gıda satın alma niyetini pozitif yönde etkilemektedir.

Keywords: Organik Gıda, Tüketim Değeri Teorisi, Ilginlik, Satın Alma Niyeti 


\section{INTRODUCTION}

Throughout the past years marketers are focusing on the trend of healthy food, which is why the sector of organic food is having more attention nowadays. Organic food is defined as the food that is processed without including any synthetic fertilizers or pesticides in which organic methods should be used while growing it. Demand for organic goods is increasing since 1990's, according to USDA it is estimated that the organic market has double-digit growth through the past years (ers.usda.gov, n.d.). According to Research Institute of Organic Agriculture "FiBL" in 2017 organic market has increased up to 533 percent since 1999 (Willer ve Lernoud, 2019:39). Consumers nowadays care about their health, that's why most people are looking for safe, healthy, and clean food which they believe that it is the organic food instead of the conventional food (Nguyen, Nguyen, Nguyen, Lobo, \& Vu, 2019:2; Hughner, McDonagh, Prothero, Shultz, \& Stanton, 2007:9). Seeking a sustainable diet and better sustainable food provisioning system are some of the reasons that people are consuming more organic food (Baudry, Allès, et al., 2017; Baudry, Péneau, et al., 2017; Seconda et al., 2017; Strassner et al., 2015; Mørk, BechLarsen, Grunert, \& Tsalis, 2017:407; Vittersø \& Tangeland, 2015:97). In addition to that, organic food purchase intention has increased due to the appearance of food toxics that were reported throughout the past years (Barnes, Vergunst \& Topp, 2009).

Organic farming's main target is to have food with no chemicals. Being exposed to the chemical substances during the farming process is associated with cancer in different body parts such as the brain, colon, stomach, pancreas, central nervous system, and kidneys (Reuben, 2010). Conventional farming affects negatively the farmers, their spouses and children who live around the farms. Some of the diseases that were reported in children living in areas near the conventional farm where pesticides are used is leukemia. Organic farming will protect the climate, will give the chance for diversifying the species, protect the water, as well as it will protect farmers and their families (Al-Janabi, 2018).

Organic market in Turkey is one of the expanding markets. Organic area has reached 107.3 million hectares, organic farmland 71.5 million hectares, with 2.8 million organic producers in 2018 (increased $55 \%$ since 2009). The share of the organic agriculture in Turkey is $1.7 \%$ in 2018, which is low compared to other countries, Liechtenstein has $38.5 \%$ of organic share, Samoa has $34.5 \%$, Austria has $24.7 \%$, Sao Tome and Principle 22.5\%, and Estonia 21.6\% (Willer et al., 2020:43). Organic agriculture industry in Turkey is considered in its starting phase but is increasing because it is considered as an important exporting country for the EU countries (Rehber \& Turhan, 2002; Polat \& Sayan, 2004:153).

This research aims to study the consumer purchase intention toward organic food by predicting what are the factors that influence purchase intention according to the consumption value theory and how involvement plays a role as a mediator between consumption value and organic food purchase intention. Involvement influences purchase intention, this result was reported while a consumer looks for product's information during the product evaluation (Richins \& Bloch, 1986). If the involvement leads to association of the product with the values, need, or benefits, then the consumption values would affect the level of involvement. Hence, it is important to explore more about consumption values and how organic food involvement mediates the relationship and affects the purchase intention toward organic food.

\section{Organic Food in Turkey}

The concept of producing organic products in Turkey started back in 1984 and 1985, mainly to support the need of the EU countries. In the early beginnings, Turkey was producing and exporting only the traditionally exported food such as dried figs and dried grapes. Later in the 1990's the export and production of organic food started to increase (Akgüngör, Miran, \& Abay, 2010:299-300). Nowadays, the different types of organic food being produced is above 200 different types (Nguyen et al., 2019). Turkey exports to 68 countries in the world, it exports to them the four popular food items; raisins, dry fig and apricot, hazelnut (Başaran et al., 2018:48). The organic area share in Turkey has increased from $0.15 \%$ in 2000 , to $1.68 \%$ in 2018 . The production also has increased strongly, organic producers were only 13,187 in 2000, and have reached 79,563 in 2018 according to the last statistics published by FiBL (statistics.fibl.org /world/operator, n.d.) (statistics.fibl.org/world/area, n.d.). The organic products that where mostly exported in 2018 were wheat and wheats product, followed by figs, fruits, hazelnut,

Submit Date: 06.10.2021, Acceptance Date: 04.11.2021, DOI NO: 10.7456/11201100/008

Research Article - This article was checked by iThenticate 
grapes, apricots, lentils, vegetables, spices, olives, chickpeas, and pistachios, which is according to the last statistics produced by the Turkish Ministry of Agriculture and Forestry. In 2018, there were $111,690.68$ tons of organic products that are produced to different countries across the globe, and the value has reached 361,128,943 Dollars. The most countries that the Turkish government has exported their organic products to are Italy, followed by Germany, Netherlands, USA, France, Belgium, Britain, Sweden, Swiss, Canada, South Korea, United Arab Emirates, Spain, and Japan (tarimorman.gov.tr., n.d.).

\section{Theory of Consumption Value}

Theory of consumption value suggests that consumers choose what they want to choose according to several consumption values. The consumption value has many aspects including the emotional value, social value, epistemic value and the functional value in terms of the quality and price (Figure 1). The customer value is a result of the customer experience with certain product, which many marketers are considering in their marketing programs (Turel, Serenko, \& Bontis, 2010:54). Each of the five values influence the purchase decision in a different way. According to the Consumption Value Theory by Sheth et al., the functional and social value will affect the consumers in terms of whether to buy the filtered or non-filtered cigarettes, but the emotional value was the driver to whether the consumer will smoke or not. Hence, all values have a differentiated performance, values will show what impacts the person's decision to choose product A or product B, brand A or B, service A or B (Sweeney \& Soutar, 2001: 205; Sheth et al., 1991). Three fundamentals are proposed in TCV: (1) the choice of a consumer is a function of several consumption values, (2) consumption values contribute differently in each situation, (3) the values are independent (Sheth et al., 1991).

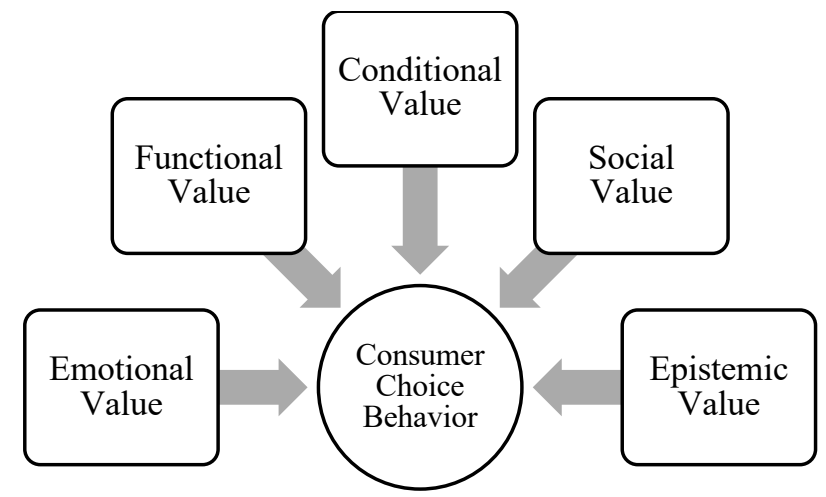

Figure 1. Theory of Consumption Values

Source: (Sheth et al., 1991)

\section{Functional Value}

Functional value is explained as the benefit and advantage the consumer gets due to the functional attributes of the demanded product. Functional value determines the consumer's usage to certain product depending on the product's function, physical performance, utility, such as having a reliable product, durable, and with a suitable price. Functional value is considered as the most important factor that affects the consumer's choice (Sheth et al., 1991). According to previous literature about organic food products and functional value, the functional value was identified by mentioning the biological features of the organic foodstuffs (Finch, 2006; Rahnama, 2017). Functional value has one of the most factors that leads to the consumption of organic food which is the health attribute according to a systematic review that reviewed 89 papers between 2005 and 2018 (Kushwah, Dhir, Sagar, \& Gupta, 2019). Quality matters to consumers because it refers to many characteristics in the organic product that protects consumer's health such as that it is free of chemicals and pesticides, it is completely natural, and better than the conventional food in terms of health (Kushwah et al., 2019). Hence, the following hypothesis is proposed in this research:

$\mathbf{H}_{1}$ : There is a positive relationship between functional value-quality and organic food purchase intention in terms of mediating the effect of involvement 
Price is another factor to consider in the functional value, in the organic market there were sixteen studies about willingness to pay for organic products and all of the studies' results showed that the price is the major barrier, however there was a study done that showed that the price isn't the major barrier and other factors such as lack of knowledge and low availability of the organic products are the barriers (Aschemann-Witzel \& Zielke, 2017). Organic food price has a contradictory issue, the reason is that consumers demand for low prices, but at the same time if they found that organic food's price is low, they might not trust it and think that it is not made according to the standards (Hughner, McDonagh, Prothero, Shultz, \& Stanton, 2007). Although prices impact the consumer's decision to purchase organic food, the decision relies on many aspects like the willingness to pay, price sensitivity, the economy, the conscious degree of the consumer, and the value for the price (Aertsens, Verbeke, Mondelaers, \& van Huylenbroeck, 2009:1145). Consequently, the following hypothesis is proposed in this research:

$\mathbf{H}_{2:}$ There is a positive relationship between functional value-price and organic food purchase intention in terms of mediating the effect of involvement

\section{Emotional Value}

Emotional value suggests that the product is able to impact the consumers feelings negatively or positively which in turn will affect the decision of purchasing the product (Sheth et al., 1991). The emotional experience will result in affecting the consumers mood in a way that leads to stronger feelings with a brand that the consumer will be attached to it (Yang \& He, 2011: 6738). Furthermore, it was stated that it is not enough for a company to have only functional value, emotional value must always be considered (Chernatony, Harris, \& Riley, 2000). The emotions that are involved in the decision of the consumer according to the literature are joy, happiness, pleasure, enjoyment, and satisfaction (Janssen, 2018; Kushwah et al., 2019). Emotions are feelings that are always connected to food, that's why emotional factors affect the food choice. Emotional value has a strong effect on purchasing organic food, (Finch, 2006; Rahnama, 2017). Consumers like to purchase organic food because they feel that they are contributing to the environment positively (Padel \& Foster, 2005). Accordingly, the following hypothesis is proposed in this research:

$\mathbf{H}_{3}$ : There is a positive relationship between emotional value and organic food purchase intention in terms of mediating the effect of involvement

\section{Social Value}

Social value is defined when the product can provide the consumer an anticipated social status. The social value is also defined as the behavior that occur when the decision is connected with positive thoughts that comes from certain group or social consequence (Sheth et al., 1991). The social value drives consumers in a way that make them choose a specific product because they are influenced by a certain social group believes like their peers, family, or colleagues believes. For example, people who consume organic food believe that people who purchase organic food are more educated and care about their health (Finch, 2006). Social values was tested among many different sectors, however, according to previous literature about organic food, the points to look at in the social value were; the product's recommendation, consumer's self-identity, the consumer's reputation in front of others, getting approval from the surrounding society (Puska, Kurki, Lähdesmäki, Siltaoja, \& Luomala, 2018; Shin, Im, Jung, \& Severt, 2018). Therefore, the following hypothesis is proposed in this research:

$\mathbf{H}_{4}$ : There is a positive relationship between social value and organic food purchase intention in terms of mediating the effect of involvement

\section{Involvement}

Involvement in general is defined as "The concept of felt involvement refers to a consumer's overall subjective feeling of personal relevance" (Celsi \& Olson, 1988). Involvement is related to the person's goals as it is also positively correlated with frequently purchasing behavior (Gainer, 1993; Mittal \& Lee, 1989). Consumers might be highly involved in products that have a high effect on self-image, that have high cost or risk, or with high societal pressure. The high involvement will let the consumer think more and learn more about the product, search more about information related to the product in order to weigh and evaluate the product's features before deciding and having intention toward purchasing the product

Research Article - This article was checked by iThenticate 
or not. On the other hand, when low involvement is present, the behavior done while purchasing the product will be due to a specific habit not due to search done on the product (Beharrell \& Denison, 1995; Verbeke \& Vackier, 2004; Cho, im, Fjermestad, \& Roxanne Hiltz, 2003; Griffith, Krampf, \& Palmer, 2001; Koufaris, 2002; Koufaris, Kambil, \& LaBarbera, 2001). Moreover, involvement influences attitude and intention. It affects the behavior outcome, for example while doing a decision the consumer might look for variety, switch to another brand, be loyal to certain brand, use product several times, or enjoy the shopping due to the involvement factor (Beharrell \& Denison, 1995; Verbeke \& Vackier, 2004). People with high involvement level do a lot of differentiation among food especially among food taste, food evaluation, and hedonic level (Bell \& Marshall, 2003). People also care about food that brings them and lead them to more healthy actions like getting involved in food that provides them good nutrients such as fruits and vegetables, and will be less involved in food that affect their health negatively such as the high fat snacks and food (Marshall \& Bell, 2004). Accordingly, the following hypothesis is proposed in this research:

H5: Involvement has a positive effect on organic food purchase intention

\section{Purchase Intention}

Purchase intention is the possibility that a costumer will purchase a specific product or service (Dodds, Monroe, \& Grewal, 1991). Purchase intention is also defined as the individual behavioral tendency toward a certain product (Bagozzi \& Burnkrant, 1979). Purchase intention is considered as the choice to perform an action, which will allows to understand the consumer's behavior to a specific product (Wang \& Yang, 2008). It is affected by factors such as the price, value, quality, external and internal motivations (Gogoi, 2013). Other factors that affect the purchase intention are the age, gender, educational level, and knowledge (Rezvani et al., 2012)

Attitude of consumers toward purchasing organic food in Turkey is affected by their values, awareness to organic food, and price. The purchase intention toward organic food of Turkish consumers is affected by being conscious of health, perceived about organic food, and care about to the environment (Selin Yilmaz \& Ilter, 2017). Also, there was no significant relationship between demographic variables of consumers in Turkey and purchase intention toward organic products, however, socially responsible consumers in Turkey have a high purchase intention toward organic products. Consumers in Turkey have low price sensitivity toward organic food, they do not often incorporate the price as a factor while purchasing the organic product (Örs, 2019).

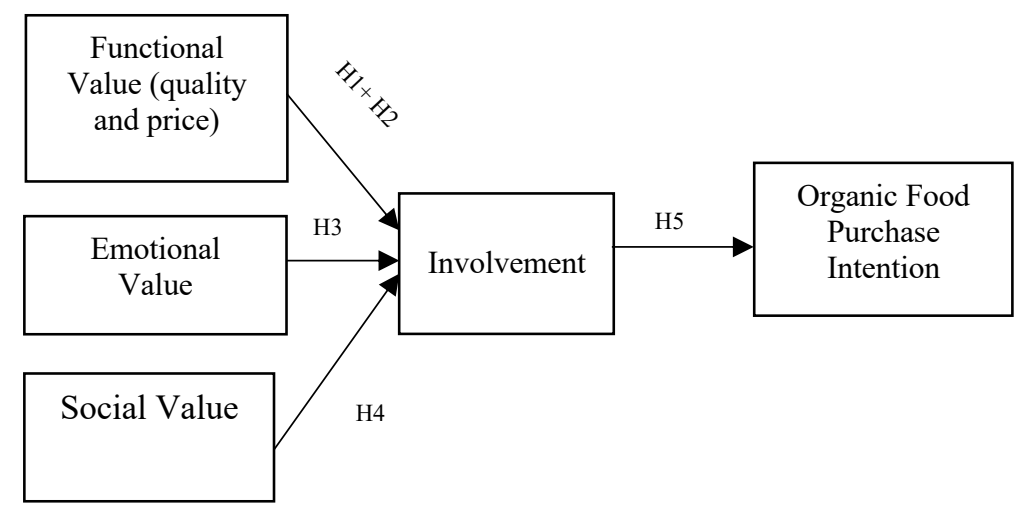

Figure 2. Research Model

\section{METHODOLOGY}

\section{Data Collection Method}

This research is descriptive research which was used quantitative data collection method by using a questionnaire as a tool by using convenience sampling method (non-probability sampling). The questionnaire is carried among Turkish consumers in Turkey. The questionnaire was sent online to 392 respondents, after the screening the data was analyzed for 386 respondents. The respondents were $64 \%$ female, and $36 \%$ were male. The age group in the questionnaire is presented across five age categories,

Research Article - This article was checked by iThenticate 
("Less than $25 "=37.6 \%, " 25-34 "=32.1 \%$, " $35-44 "=22.3 \%$, " $45-54 "=5.4 \%$, above $55=2.6 \%$ of the respondents). The sample studied constitute of $67.1 \%$ single respondents, and $32.9 \%$ married. It has $48.2 \%$ of the respondents with a bachelor's degree, $27.2 \%$ of the respondents with a master's degree. Majority of the respondents have the lowest income level, which is 2020 Turkish Liras and below, they constitute of $35.5 \%$ of the sample study. The demographics are shown in Table 1.

\section{Measures}

The questionnaire design was based on previous literature from different authors who measured the consumption values. The social and functional values scale are adapted from Sweeney \& Soutar (2001), with having four items to measure functional value (price), four items for functional value (quality), and four items to measure the social value. The emotional value scale is adapted from Ajzen \& Fishbein (1980) by using five items to measure it. The involvement scale and the purchase intention scale is adapted from Teng \& Lu (2016), four items are used to measure each of the involvement scale and the purchase intention scale. The questionnaire is carried among Turkish consumers in Turkey, it was sent online and manually in a convenient way. In all parts except the demographics, five-point Likert scale was used to know whether the consumers agree or disagree with the statements listed, the scale is from "strongly disagree" along to "strongly agree".

Table 1. Demographics of The Sample (N=386)

\begin{tabular}{lll}
\hline & Frequency & Percent \\
\hline 1- Gender & 139 & 36.0 \\
Male & 247 & 64.0 \\
Female & & \\
2-Age & 145 & 37.6 \\
Less than 25 & 124 & 32.1 \\
25-34 & 86 & 22.3 \\
35-44 & 21 & 5.4 \\
45-54 & 10 & 2.6 \\
>or = to 55 & & \\
3-Marital Status & 259 & 67.1 \\
Single & 127 & 32.9 \\
Married & & \\
4-Educational Level & 9 & 2.3 \\
Primary School & 65 & 16.8 \\
High School & 186 & 48.2 \\
Bachelor's Degree & 105 & 27.2 \\
Master's Degree & 21 & 5.4 \\
PHD Degree & & \\
5-Income Per Month & 137 & 35.5 \\
2020 TL and Below & 86 & 22.3 \\
2021-3500 TL & 75 & 19.4 \\
3501-5000 TL & 54 & 14.0 \\
5001-7000 & $\mathbf{3 4}$ & $\mathbf{8 . 8}$ \\
7001 and more & & \\
\hline
\end{tabular}




\section{Data Analysis and Findings}

The inferential statistics are analyzed, and they include the Exploratory Factor Analysis (EFA) and Confirmatory Factor Analysis (CFA) that help to understand the relationship between the variables and to know the variability and reliability of the dimensions. After that, the multiple regression assumptions were done. Structural equation modelling (SEM) was used to test the hypotheses. SEM is a method designed to analyze the hypothesized model and it is done for complex models and other several types. Demographics are analyzed by using the Statistical Package for Social Sciences (SPSS) version 22.00, while AMOS software version 22.00 are used for the EFA and CFA.

\section{Normality Assessment}

Normality is done for parametric statistical analysis. The values for both skewness and kurtosis must not be above 3 nor below -3 (Dori'c et al., 2009). Table 2 shows that both skewness and kurtosis values are not below -3 nor above 3 which indicates that the data is normally distributed

Table 2. Skewness and Kurtosis

\begin{tabular}{|c|c|c|}
\hline Variables & Skewness & Kurtosis \\
\hline FV-Quality1 & -.519 & -.434 \\
\hline FV-Quality2 & -.695 & .020 \\
\hline FV-Quality3 & -.783 & -.045 \\
\hline FV-Quality4 & -.640 & -.210 \\
\hline FV_Price1 & .804 & -.047 \\
\hline FV_Price2 & -.078 & -.645 \\
\hline FV_Price3 & -.121 & -.948 \\
\hline FV_Price4 & .920 & .346 \\
\hline Social_Value1 & .108 & -1.079 \\
\hline Social_Value2 & -.007 & -1.207 \\
\hline Social_Value3 & .001 & -1.174 \\
\hline Social_Value4 & .055 & -1.101 \\
\hline Emotional_Value1 & -.407 & -.889 \\
\hline Emotional_Value2 & -.708 & -.449 \\
\hline Emotional_Value3 & -.748 & -.185 \\
\hline Emotional_Value4 & -.657 & -.381 \\
\hline Emotional_Value5 & -.943 & .479 \\
\hline Involvement 1 & -.967 & .280 \\
\hline Involvement 2 & -.435 & -.536 \\
\hline Involvement3 & -.096 & -.653 \\
\hline Involvement 4 & -.096 & -.879 \\
\hline Purchase_Inten 1 & -.838 & .043 \\
\hline Purchase_Inten2 & -.741 & .008 \\
\hline Purchase_Inten3 & -.903 & .209 \\
\hline Purchase_Inten4 & -.745 & -.205 \\
\hline
\end{tabular}

In Table 3, the pattern matrix is displayed; it shows that all 6 factors are perfectly loading (except for the item involvement 1 in the involvement factor was removed due to presence of cross loading). As evidence of convergent validity, the loadings are above 0.5 , and as an evidence of discriminant validity there are no strong cross loadings. 
Table 3. Pattern Matrix

\begin{tabular}{|c|c|c|c|c|c|c|}
\hline Factor & 1 & 2 & 3 & 4 & 5 & 6 \\
\hline FV_Quality1 & & & .857 & & & \\
\hline FV_Quality2 & & & .954 & & & \\
\hline FV_Quality3 & & & .800 & & & \\
\hline FV_Quality4 & & & .712 & & & \\
\hline FV_Price1 & & & & & & .817 \\
\hline FV_Price2 & & & & & & .671 \\
\hline FV_Price3 & & & & & & .579 \\
\hline FV_Price4 & & & & & & .793 \\
\hline Social_Value1 & & .787 & & & & \\
\hline Social_Value2 & & .892 & & & & \\
\hline Social_Value3 & & .864 & & & & \\
\hline Social_Value4 & & .883 & & & & \\
\hline Emotional_Value1 & .628 & & & & & \\
\hline Emotional_Value2 & .655 & & & & & \\
\hline Emotional_Value3 & .857 & & & & & \\
\hline Emotional_Value4 & 1.077 & & & & & \\
\hline Emotional_Value5 & .811 & & & & & \\
\hline Involvement2 & & & & & .649 & \\
\hline Involvement 3 & & & & & .958 & \\
\hline Involvement4 & & & & & .785 & \\
\hline Purchase_Inten1 & & & & .820 & & \\
\hline Purchase_Inten2 & & & & .960 & & \\
\hline Purchase_Inten3 & & & & .752 & & \\
\hline Purchase_Inten4 & & & & .688 & & \\
\hline
\end{tabular}

\section{Variables Reliability Results}

Reliability of the factors is checked by looking at the Cronbach's alpha scores. The values should be above 0.70 to indicate a good internal consistency (Hair, 2013:33). In the table 4 all the of the Cronbach's alpha scores are above 0.70 .

Table 4. Variables Reliability Results

\begin{tabular}{lll}
\hline Variables & Total Items & Cronbach's alpha $\boldsymbol{\alpha}$ \\
\hline Functional Value- Quality & 4 & .892 \\
& & \\
Functional Value- Price & 4 & .825 \\
& & \\
Social Value & 4 & .920 \\
Emotional Value & 5 & .922 \\
Involvement & 3 & .883 \\
Purchase Intention & $\mathbf{4}$ & $\mathbf{. 9 2 2}$ \\
\hline
\end{tabular}

\section{Validity and Reliability Results}

In Table 5 the values show a convergent validity that is evidenced by the AVE scores which are all above 0.5 . The scores show reliability as well, which is evidenced by CR scores that are all above 0.7 . The scores resulted a discriminant validity based on the square root of the AVE being greater than any enter factor correlation on this matrix. 
Table 5. Validity and Reliability Results

\begin{tabular}{|c|c|c|c|c|c|c|c|c|c|c|}
\hline & CR & AVE & MSV & $\operatorname{MaxR}(H)$ & Involvement & Emotional & Social & Quality & Intention & Price \\
\hline $\begin{array}{l}\text { Involvem } \\
\text { ent }\end{array}$ & 0.886 & 0.722 & 0.596 & 0.895 & 0.849 & & & & & \\
\hline Emotional & 0.925 & 0.712 & 0.510 & 0.928 & 0.530 & 0.844 & & & & \\
\hline Social & 0.914 & 0.729 & 0.266 & 0.925 & 0.227 & 0.516 & 0.854 & & & \\
\hline Quality & 0.886 & 0.662 & 0.286 & 0.908 & 0.349 & 0.512 & 0.278 & 0.814 & & \\
\hline Intention & 0.917 & 0.736 & 0.596 & 0.923 & 0.772 & 0.714 & 0.259 & 0.499 & 0.858 & \\
\hline Price & 0.801 & 0.512 & 0.286 & 0.860 & 0.407 & 0.526 & 0.394 & 0.535 & 0.476 & 0.715 \\
\hline
\end{tabular}

\section{Testing Hypothesis}

Structural model analysis is done to check the relationship between the latent variables and observable variables. Mediation is analyzed by checking the direct and indirect effects. The indirect effects determines whether there is a mediation or not (Schreiber et al., 2006:328). In table 6 it is noticed that the $\mathrm{CMIN} / \mathrm{DF}=2.687$ which is considered as acceptable fit according to the threshold that is more or equal to 2 and less or equal to 3 (Boyac1 \& Atalay, 2016:141). The p-value showed a significant result where $p=0.000$. AGFI is equal to 0.842 which is considered as acceptable fit. Values for AGFI which are $.90 \leq \mathrm{AGFI} \leq 1.00$ are considered as perfect fit, whereas values $.80 \leq \mathrm{AGFI} \leq .90$ are considered as acceptable fit. GFI in this study is 0.877 which is considered as acceptable fit. Values of GFI $.90 \leq$ GFI $\leq 1.00$ are considered as perfect fit and $.85 \leq \mathrm{GFI} \leq 90$ are considered acceptable fit (Dilek, Boyac1 \& Atalay, 2016:141). CFI value is 0.945 which is considered as acceptable fit. Values of CFI $.95 \leq \mathrm{CFI} \leq$ 1.00 are considered as perfect fit whereas values $.90 \leq \mathrm{CFI} \leq .95$ are considered as acceptable fit. The value of RMSEA is 0.066 which results in acceptable fit model. The RMSEA values of $.00 \leq$ RMSEA $\leq .05$ are considered as perfect fit and $.05 \leq$ RMSEA $\leq .08$ as acceptable fit. Standardized Root Mean Square (SRMR is 0.0706) which is according to the criteria considered as acceptable fit. SRMR values of $.00 \leq$ SRMR $\leq .05$ are considered as perfect fit and values of $.05 \leq$ SRMR $\leq .10$ are considered as acceptable fit (Boyac1 \& Atalay, 2016:141). Based on the values in table 6, the model has a good fit, and we can move to the hypothesis testing.

Table 6. Model Fit Scores of the Structural Model

\begin{tabular}{|c|c|c|c|}
\hline Indices & $\begin{array}{l}\text { Obtained Fit } \\
\text { Indices }\end{array}$ & Threshold & Result \\
\hline Chi-square/ df (CMIN/DF) & 2.687 & $<3$ & Acceptable Fit \\
\hline Goodness-of-fit index (GFI) & .877 & $>0.90$ & Acceptable Fit \\
\hline $\begin{array}{l}\text { Adjusted } \\
\text { (AGFI) }\end{array}$ goodness-of-fit $\quad$ index & .842 & $>0.80$ & Acceptable Fit \\
\hline Comparative Fit Index (CFI) & .945 & $\geq 0.95$ & Acceptable Fit \\
\hline $\begin{array}{l}\text { Root Mean Square Error of } \\
\text { Approximation (REMSA) }\end{array}$ & .066 & $<0.05$ & Acceptable Fit \\
\hline $\begin{array}{l}\text { Standardized Root Mean Square } \\
\text { (SRMR) }\end{array}$ & .0706 & $<0.09$ & Acceptable Fit \\
\hline
\end{tabular}

Meditation analysis allows the researchers to test the mediator impact on the relationship between the independent and dependent variable. In order to check for the mediation, the mediator effect on the dependent variable should be examined, as well as the effect of the independent variable on the dependent variable. To prove the mediation, a strong correlation between the independent variable, dependent variable, and mediation variable should be reported (Hair, 2013:33). In the table 7 results of the mediation are shown:

Research Article - This article was checked by iThenticate 
Table 7. Meditation Results

\begin{tabular}{|c|c|c|c|c|}
\hline Hypothesis & $\begin{array}{l}\text { Direct Beta } \\
\text { without } \\
\text { mediator }\end{array}$ & $\begin{array}{l}\text { Direct with } \\
\text { mediator }\end{array}$ & $\begin{array}{l}\text { Standardized } \\
\text { indirect effect } \\
\text { (two tailed } \\
\text { significance) (BC) }\end{array}$ & Result \\
\hline $\begin{array}{l}\text { Functional Value } \\
\text { (quality) } \\
\text { Involvement- } \\
\text { purchase intention }\end{array}$ & $.142(.007)$ & $.103(.020)$ & $.041(.366)$ & $\begin{array}{l}\text { No mediation (indirect } \\
\text { is not significant) }\end{array}$ \\
\hline $\begin{array}{l}\text { Functional Value } \\
\text { (price) } \\
\text { Involvement- } \\
\text { purchase intention }\end{array}$ & $.117(.040)$ & $.028(.559)$ & $.089(.018)$ & $\begin{array}{l}\text { Full mediation (direct } \\
\text { effect was significant } \\
\text { prior to the addition of } \\
\text { the mediator, } \\
\text { insignificant after } \\
\text { adding mediator, and } \\
\text { indirect is significant) }\end{array}$ \\
\hline $\begin{array}{l}\text { Emotional Value- } \\
\text { Involvement- } \\
\text { purchase intention }\end{array}$ & $.668(* * *)$ & $.407(* * *)$ & $.261(.001)$ & $\begin{array}{l}\text { Partially mediated } \\
\text { (direct with mediator } \\
\text { and indirect effect are } \\
\text { significant) }\end{array}$ \\
\hline $\begin{array}{l}\text { Social Value- } \\
\text { Involvement- } \\
\text { purchase intention }\end{array}$ & $-.170(* * *)$ & $-.113(.006)$ & $-.059(.082)$ & $\begin{array}{l}\text { No mediation (indirect } \\
\text { is not significant) }\end{array}$ \\
\hline $\begin{array}{l}\text { Involvement- } \\
\text { purchase intention }\end{array}$ & $.547(* * *)$ & - & - & $\begin{array}{l}\text { Involvement } \\
\text { significantly affects } \\
\text { purchase intention }\end{array}$ \\
\hline
\end{tabular}

$\mathrm{H}_{1}$ : There is a positive relationship between functional value-quality and organic food purchase intention in terms of mediating the effect of involvement by looking at table 7, the results' interpretation shows that involvement doesn't mediate the relationship between functional value-quality and purchase intention, which means that hypothesis $\left(\mathrm{H}_{1}\right)$ is not accepted, and null hypothesis is accepted.

$\mathrm{H}_{2:}$ There is a positive relationship between functional value-price and organic food purchase intention in terms of mediating the effect of involvement.

According to Table 7, involvement fully mediates the relationship between functional value-price and purchase intention, which means that hypothesis $\left(\mathrm{H}_{2}\right)$ is accepted.

$\mathrm{H}_{3}$ : There is a positive relationship between emotional value and organic food purchase intention in terms of mediating the effect of involvement.

From Table 7 it is noticed that involvement partially mediates the relationship between emotional value and purchase intention, which means that hypothesis $\left(\mathrm{H}_{3}\right)$ is accepted

$\mathrm{H}_{4}$ : There is a positive relationship between social value and organic food purchase intention in terms of mediating the effect of involvement.

Involvement doesn't mediate the relationship between social value and purchase intention, which means that hypothesis $\left(\mathrm{H}_{4}\right)$ is not accepted, and null hypothesis is accepted.

$\mathrm{H}_{5}$ : Involvement has positive effect on organic food purchase intention

Involvement positively affects the purchase intention according to the direct effect result shown in Table 7.

\section{CONCLUSION}

The functional value is measured by two aspects, first one is the functional value in terms of quality, the second one in terms of price. To start first with the functional value-quality the results showed that there is a positive direct relationship between the functional value quality and purchase intention (without the mediator), however, the indirect effect is insignificant, hence, involvement does not mediate the relationship between functional value quality and purchase intention. In another words, consumers will buy the organic food for its quality, they don't need to be involved in the organic food to buy it, believing

Research Article - This article was checked by iThenticate 
that the product is high quality is enough for them. However, when it comes to the functional valueprice, there is a positive direct relationship between the functional value-price and purchase intention, there is also significant indirect effect, and it is a full mediation. This indicates that people who purchase organic food are highly involved with it, to the extent that they are willing to pay the higher price for organic food. This finding will help marketers to target consumers who are highly involved with organic food.

Second, results for emotional value showed that there is a direct positive relationship between emotional value and purchase intention without the mediator, and there is also a partial mediation, where involvement partially mediates the relationship between emotional value and organic food purchase intention. This shows that people who are involved with organic food and concerned about the emotional value toward organic food (in terms of consumers respecting farmers wellbeing, feeling better about their selves, feeling that they are responsible, conscious, care about the environment), are more likely to purchase organic food

Third, results for social value showed that involvement does not mediate the relationship between the social value and purchase intention of organic food. However, there is a significant negative relationship between the social value organic food purchase intention without the mediation of involvement. This means that consumers do not purchase organic food because they feel that they are more acceptable, or that the organic food gives them social approval or good impression on other people when they purchase organic food, they purchase it due to reasons other than the social value.

Last thing is the involvement, the results of the direct relationship between involvement and purchase intention showed a significant positive relationship and this indicates that consumers who are highly involved in a certain product are more likely to purchase that product compared with consumers who have low involvement. Hence involvement is a factor that plays a good role in affecting the purchase intention.

To conclude, functional value and emotional value have a positive significant relationship with the purchase intention of organic food without including the mediator, and there is a negative significant relationship between the social value and organic food purchase intention without the inclusion of the mediator (involvement). However, after the addition of involvement as a mediator, it resulted with a full mediation between the functional value- price, partial mediation with the emotional value and the organic food purchase intention. Whereas it shows no mediation between functional value-quality and social value with the organic food purchase intention. Hence, Turkish consumers who are highly involved in the organic food buy the product no matter how high the price is. Emotionally involved Turkish consumers purchase organic food. As a result, the marketers may target these two groups when they need to increase the purchases of organic market.

\section{LIMITATIONS AND RECOMMENDATIONS}

The study has few limitations, to start with the first one; non-probability sampling was used, the convenience method, which means respondents does not represent the population as if it was probability sampling. The survey was collected by distributing it online and some consumers of organic food might not have access to the internet. Another limitation is not having two groups (organic consumers and non-organic consumers). Having two groups helps to understand the difference between both groups which allows marketers to understand more why non-organic consumers do not purchase organic food for example.

According to this research; it is recommended that marketers target Turkish consumers with high involvement in the organic food. As it appears that involvement has a positive effect on the purchase intention of organic food. It is also advised that marketers take into consideration the consumption values tested in this study and notice that they all have significant effect on the purchase intention of organic food. Government might take into consideration the support for the organic market in order to help all Turkish consumers, especially the non-involved ones in purchasing organic food. Moreover, it is recommended to promote organic food by targeting consumers who care about the emotional value. Another recommendation is to find a strategy that targets the non-involved Turkish consumers.

Submit Date: 06.10.2021, Acceptance Date: 04.11.2021, DOI NO: 10.7456/11201100/008

Research Article - This article was checked by iThenticate 
The study shows that it is beneficial to do further studies in the same area to determine furthermore the needed marketing strategy, especially that in Turkey there is no previous study that had both consumption value theory and involvement as a mediator, hence studies to confirm the results is needed with the following suggestions:

- Implement the same research but add the other two remaining consumption values which are the epistemic value and conditional value

- Implement the same study but with having two groups (organic and non-organic consumers)

- $\quad$ Future studies might include a mediator other than the mediator used (involvement) to the research model.

\section{REFERENCES}

Aertsens, J., Verbeke, W., Mondelaers, K., \& Van Huylenbroeck, G. (2009). Personal determinants of organic food consumption: A review. British Food Journal, 111(10), 1140-1167.

https://doi.org/10.1108/00070700910992961

Ajzen I, Fishbein M (1980). Understanding Attitudes and Predicting Social Behavior. Nwe Jersey: Prentice Hall

Akgüngör, S., Miran, B., \& Abay, C., (2010). Consumer Willingness to Pay for Organic Food in Urban Turkey. Journal of International Food \& Agribusiness Marketing. 22 (3-4), 299-313. https://doi.org/10.1080/08974431003641455

Al-Janabi, T. (2018). Perception and training needs of Mississippi State University Extension agents and the level of demand they receive for information in organic agriculture. (Publication No. 10978407) [Doctoral Dissertation, College of Agriculture and Life Sciences]. ProQuest Diseerattion \& Theses Global

Aschemann -Witzel, J., \& Zielke, S. (2017, March 1). Can't Buy Me Green? A Review of Consumer Perceptions of and Behavior Toward the Price of Organic Food. Journal of Consumer Affairs, 51, 211251. https://doi.org/10.1111/joca.12092

Barnes, A. P., Vergunst, P., \& Topp, K. (2009). Assessing the consumer perception of the term "organic": A citizens' jury approach. British Food Journal, 111(2), 155-164. https://doi.org/10.1108/00070700910931977

Başaran, B., Konyali, S., \& Oraman, Y. (2018). AN OVERVIEW OF ORGANIC PRODUCER ORGANIZATIONS IN TURKEY. New Knowledge Journal of Science, 7(2). Retrieved from http://www.science.uard.bg/index.php/newknowledge/article/view/360

Baudry, J., Allès, B., Péneau, S., Touvier, M., Méjean, C., Hercberg, S., ... Kesse-Guyot, E. (2017). Dietary intakes and diet quality according to levels of organic food consumption by French adults: Cross-sectional findings from the NutriNet-Santé Cohort Study. Public Health Nutrition, 20(4), 638648. https://doi.org/10.1017/S1368980016002718

Baudry, J., Péneau, S., Allès, B., Touvier, M., Hercberg, S., Galan, P., ... Kesse-Guyot, E. (2017). Food Choice Motives When Purchasing in Organic and Conventional Consumer Clusters: Focus on Sustainable Concerns (The NutriNet-Santé Cohort Study). Nutrients, 9(2), 88. https://doi.org/10.3390/nu9020088

Beharrell, B., \& Denison, T. J. (1995). Involvement in a Routine Food Shopping Context. British Food Journal, 97(4), 24-29. https://doi.org/10.1108/00070709510085648

Bell, R., \& Marshall, D. W. (2003, June 1). The construct of food involvement in behavioral research: Scale development and validation. Appetite, 40, 235-244. https://doi.org/10.1016/S01956663(03)00009-6

Boyacı D.Ş \& Atalay, N. (2016). A Scale Development for 21st Century Skills of Primary School 
Students: A Validity and Reliability Study 1. In International Journal (Vol. 9). Retrieved from www.eiji.net

Celsi, R. L., \& Olson, J. C. (1988). The Role of Involvement in Attention and Comprehension Processes. Journal of Consumer Research, 15(2), 210. https://doi.org/10.1086/209158

Chernatony, L., Harris, F., \& Dall'Olmo Riley, F. (2000). Added value: its nature, roles and sustainability. European Journal of Marketing, 34(1/2), 39-56. https://doi.org/10.1108/03090560010306197

Cho, Y., im, I., Fjermestad, J., \& Roxanne Hiltz, S. (2003). The impact of product category on customer dissatisfaction in cyberspace. Business Process Management Journal, 9(5), 635-651. https://doi.org/10.1108/14637150310496730

Dodds, W. B., Monroe, K. B., \& Grewal, D. (1991). Effects of Price, Brand, and Store Information on Buyers' Product Evaluations. Journal of Marketing Research, 28(3), 307-319. https://doi.org/10.1177/002224379102800305

Dori'c, D.-D., Nikoli'c, E., Dori'c, N.--D., Vesna, ·, Jevremovi'c, J., \& Mališíc, J. M. (2009). On measuring skewness and kurtosis. Qual Quant, 43, 481-493. https://doi.org/10.1007/s11135-007-91289

FiBL Statistics. (n.d.). FiBL Statistics-Area. Retrieved April 23, 2020, from https://statistics.fibl.org/world/area-

world.html?tx_statisticdata_pi1\%5Bcontroller\%5D=Element2Item\&cHash=f367262839ab9ca2e7ac1f $333 \mathrm{fbb} 1 \mathrm{ca} 2$

FiBL Statistics - Operators . (n.d.). FiBL Statistics-Operators. Retrieved April 23, 2020, from https://statistics.fibl.org/world/operator-

world.html?tx_statisticdata_pi1\%5Bcontroller\%5D=Element2Item\&cHash=935c97b37cdd0875056cd ac4686d0079

Finch, J. E. (2006). The Impact of Personal Consumption Values and Beliefs on Organic Food Purchase Behavior. 11(4), 63-76. https://doi.org/10.1300/J038v11n04_05

Gainer, B. (1993). An empirical investigation of the role of involvement with a gendered product. Psychology and Marketing, 10(4), 265-283. https://doi.org/10.1002/mar.4220100403

Gogoi, B. J. (2013). Study Of Antecedents Of Purchase Intention And Its Effect On Brand Loyalty Of Private Label Brand Of Apparel. In International Journal of Sales \& Marketing Management Research and Development (Vol. 3).

Griffith, D. A., Krampf, R. F., \& Palmer, J. W. (2001). The role of interface in electronic commerce: Consumer involvement with print versus on-line catalogs. International Journal of Electronic Commerce, 5(4), 135-153. https://doi.org/10.1080/10864415.2001.11044219

Hair, J. F., Black, W. C., Babin, B. J., \& Anderson, R. E. (2013). Multivariate data analysis: Pearson new international edition. Pearson Higher Ed.

Hughner, R. S., McDonagh, P., Prothero, A., Shultz, C. J., \& Stanton, J. (2007). Who are organic food consumers? A compilation and review of why people purchase organic food. Journal of Consumer Behaviour, 6(2-3), 94-110. https://doi.org/10.1002/cb.210

Janssen, M. (2018). Determinants of organic food purchases: Evidence from household panel data. Food Quality and Preference, 68, 19-28. https://doi.org/10.1016/j.foodqual.2018.02.002

Koufaris, M. (2002). Applying the Technology Acceptance Model and flow theory to online Consumer Behavior. Information Systems Research, 13(2), 205-223. https://doi.org/10.1287/isre.13.2.205.83

Koufaris, M., Kambil, A., \& LaBarbera, P. A. (2001). Consumer behavior in Web-based commerce: An empirical study. International Journal of Electronic Commerce, 6(2), 115-138. 
https://doi.org/10.1080/10864415.2001.11044233

Kushwah, S., Dhir, A., Sagar, M., \& Gupta, B. (2019, December 1). Determinants of organic food consumption. A systematic literature review on motives and barriers. Appetite, Vol. 143, p. 104402. https://doi.org/10.1016/j.appet.2019.104402

Marshall, D., \& Bell, R. (2004). Relating the food involvement scale to demographic variables, food choice and other constructs. Food Quality and Preference, 15(7-8 SPEC.ISS.), 871-879. https://doi.org/10.1016/j.foodqual.2004.06.003

Mittal, B., \& Lee, M. S. (1989). A causal model of consumer involvement. Journal of Economic Psychology, 10(3), 363-389. https://doi.org/10.1016/0167-4870(89)90030-5

Mørk, T., Bech-Larsen, T., Grunert, K. G., \& Tsalis, G. (2017). Determinants of citizen acceptance of environmental policy regulating consumption in public settings: Organic food in public institutions. Journal of Cleaner Production, 148, 407-414. https://doi.org/10.1016/j.jclepro.2017.01.139

Nguyen, H. V., Nguyen, N., Nguyen, B. K., Lobo, A., \& Vu, P. A. (2019). Organic food purchases in an emerging market: The influence of consumers' personal factors and green marketing practices of food stores. International Journal of Environmental Research and Public Health, 16(6). https://doi.org/10.3390/ijerph16061037

Örs, M. (2019). Organik Ürün Satınalma Niyetine Etki Eden Faktörlerde Fiyat Algısının Düzenleyici Rolü. Business \& Management Studies: An International Journal, 7(2), 891-925. https://doi.org/10.15295/bmij.v7i2.1102

Padel, S., \& Foster, C. (2005). Exploring the gap between attitudes and behaviour: Understanding why consumers buy or do not buy organic food. British Food Journal, 107(8), 606-625. https://doi.org/10.1108/00070700510611002

Polat, M., \& Sayan, Y. (2004). Development of organic animal production in Turkey. $3^{\text {rd }}$ SAFO workshop, Falenty, Poland.

Puska, P., Kurki, S., Lähdesmäki, M., Siltaoja, M., \& Luomala, H. (2018). Sweet taste of prosocial status signaling: When eating organic foods makes you happy and hopeful. Appetite, 121, 348-359. https://doi.org/10.1016/j.appet.2017.11.102

Rahnama, H. (2017). Effect of Consumption Values on Women's Choice Behavior Toward Organic Foods: The Case of Organic Yogurt in Iran. Journal of Food Products Marketing, 23(2), 144-166. https://doi.org/10.1080/10454446.2017.1244790

Rehber, E., \& Turhan, S. (2002). Prospects and challenges for developing countries in trade and production of organic food and fibers: The case of Turkey. British Food Journal, 104, 371-390. https://doi.org/10.1108/00070700210435380

Republic Of Turkey Ministry Of Agriculture And Forestry. (n.d.). Retrieved April 25, 2020, from https://www.tarimorman.gov.tr/Sayfalar/EN/AnaSayfa.aspx

Reuben, S. H. (2010). Reducing Environmental Cancer Risk: What We Can Do Now - National Instiute of Health.

Rezvani, S., Javadian Dehkordi, G., Sabbir Rahman, M., Fouladivanda, F., Habibi, M., \& Eghtebasi, S. (2012). A Conceptual Study on the Country of Origin Effect on Consumer Purchase Intention. Asian Social Science, 8(12). https://doi.org/10.5539/ass.v8n12p205

Richins, M. L., \& Bloch, P. H. (1986). After the New Wears off: The Temporal Context of Product Involvement. Journal of Consumer Research, 13(2), 280. https://doi.org/10.1086/209067

Schreiber, J. B., Nora, A., Stage, F. K., Barlow, E. A., \& King, J. (2006). Reporting Structural Equation Modeling and Confirmatory Factor Analysis Results: A Review. The Journal of Educational Research, 99(6), 323-338. https://doi.org/10.3200/JOER.99.6.323-338 
Seconda, L., Baudry, J., Allès, B., Hamza, O., Boizot-Szantai, C., Soler, L.-G., ... Kesse-Guyot, E. (2017). Assessment of the Sustainability of the Mediterranean Diet Combined with Organic Food Consumption: An Individual Behaviour Approach. Nutrients, 9(1), 61. https://doi.org/10.3390/nu9010061

Selin Yilmaz, B., \& Ilter, B. (2107). Motives Underlying Organic Food Consumption in Turkey: Impact of Health, Environment and Consumer Values on Purchase Intentions. Economics World, 5(4), 333345. https://doi.org/10.17265/2328-7144/2017.04.006

Sheth, J. N., Newman, B. I., \& Gross, B. L. (1991). Why we buy what we buy: A theory of consumption values. Journal of Business Research, 22(2), 159-170. https://doi.org/10.1016/0148-2963(91)90050-8

Shin, Y. H., Im, J., Jung, S. E., \& Severt, K. (2018). Motivations behind Consumers' Organic Menu Choices: The Role of Environmental Concern, Social Value, and Health Consciousness. Journal of Quality Assurance in Hospitality \& Tourism, 20(1), 107-122. https://doi.org/10.1080/1528008X.2018.1483288

Strassner, C., Cavoski, I., Di Cagno, R., Kahl, J., Kesse-Guyot, E., Lairon, D., ... Stolze, M. (2015). How the Organic Food System Supports Sustainable Diets and Translates These into Practice. Frontiers in Nutrition, 2, 19. https://doi.org/10.3389/fnut.2015.00019

Sweeney, J. C., \& Soutar, G. N. (2001). Consumer perceived value: The development of a multiple item scale. Journal of Retailing, 77(2), 203-220. https://doi.org/10.1016/S0022-4359(01)00041-0

Teng, C. C., \& Lu, C. H. (2016). Organic food consumption in Taiwan: Motives, involvement, and purchase intention under the moderating role of uncertainty. Appetite, 105, 95-105. https://doi.org/10.1016/j.appet.2016.05.006

Turel, O., Serenko, A., \& Bontis, N. (2010). User acceptance of hedonic digital artifacts: A theory of consumption values perspective. Information and Management, 47(1), 53-59. https://doi.org/10.1016/j.im.2009.10.002

United States Department of Agriculture. (n.d.). USDA ERS - Organic Agriculture. Retrieved November 1, 2019, from https://www.ers.usda.gov/topics/natural-resources-environment/organicagriculture/

Verbeke, W., \& Vackier, I. (2004). Profile and effects of consumer involvement in fresh meat. Meat Science, 67(1), 159-168. https://doi.org/10.1016/j.meatsci.2003.09.017

Vitters $\varnothing$, G., \& Tangeland, T. (2015). The role of consumers in transitions towards sustainable food consumption. the case of organic food in Norway. Journal of Cleaner Production, 92, 91-99. https://doi.org/10.1016/j.jclepro.2014.12.055

Wang, X., \& Yang, Z. (2008). Does country-of-origin matter in the relationship between brand personality and purchase intention in emerging economies? Evidence from China's auto industry. International Marketing Review, 25(4), 458-474. https://doi.org/10.1108/02651330810887495

Willer, Hegla, \& Lernoud, J. (2019). The World of Organic Agriculture. In Hegla Willer \& J. Lernoud (Eds.), The World of Organic Agriculture (20th ed.). https://doi.org/10.4324/9781849775991

Willer, Helga, Schlatter, B., Trávníček, J., Kemper, L., \& Lernoud, J. (2020). The World Organic Agriculture Statistics and Emerging Trends 2020 (Helga Willer, B. Schlatter, J. Travnicek, L. Kemper, $\&$ J. Lernoud, Eds.).(21 ${ }^{\text {st }}$ ed.). Retrieved from https://shop.fibl.org/CHde/mwdownloads/download/link/id/1294/?ref=1

Yang, Z.-Y., \& He, L.-Y. (2011). Goal, customer experience and purchase intention in a retail context in China: An empirical study. African Journal of Business Management, 5(16), 6738-6746. https://doi.org/10.5897/AJBM10.1287 